\title{
ВИКОРИСТАННЯ МІЖДИСЦИПЛІНАРНИХ ЗВ'ЯЗКІВ ЯК УМОВА ЯКІСНОЇ ПІДГОТОВКИ СТУДЕНТІВ ДО ЛІЦЕНЗІЙНОГО ІСПИТУ «КРОК 1. ЗАГАЛЬНА ЛІКАРСЬКА ПІДГОТОВКА»
}

\author{
O. Z. Ivanchenko, O. Z. Melnikova, L. N. Sergeeva \\ Zaporizhzhia State Medical University \\ THE USE OF INTERDISCIPLINARY LINKS AS A CONDITION OF \\ QUALITY PREPARATION OF STUDENTS FOR THE LICENSE \\ EXAMINATION “STEP-1. GENERAL MEDICAL TRAINING”
}

\begin{abstract}
Анотація. У статті проаналізовано роль міждисциплінарних зв'язків між медичною і біологічною фізикою та нормальною фізіологією людини для підготовки студентів до ліцензійного іспиту «Крок 1. Загальна лікарська підготовка», знайдених шляхом порівняння навчальних програм з обох дисциплін. Розглянуто тестові питання з нормальної фізіології у базі тестів для підготовки й у буклетах для складання іспиту, і визначено завдання, які студенти виконують вже на першому курсі в процесі вивчення медичної і біологічної фізики. Показано, що у базі тестів число таких завдань складає в середньому 8,7 \% загальної кількості питань з нормальної фізіології людини, тоді як у буклетах іспиту - в середньому 22 \%. Такі дані свідчать про необхідність широкого залучення міждисциплінарних зв’язків у вивченні обох наук, що дозволить уникнути дублювання навчального матеріалу в процесі навчання, відкриваючи перспективи для ретельнішого освоєння студентами програми з нормальної фізіології.

Ключові слова: Крок 1; міждисциплінарні зв’язки; медична і біологічна фізика; нормальна фізіологія.

Abstract. The article analyzes the role of interdisciplinary links between medical and biological physics and normal human physiology, found by comparing curricula in both disciplines, in preparing students for the licensing exam "STEP-1. General medical training". Test questions on normal physiology were considered in the test data base for preparation and in booklets for passing the exam, and tasks that students are taught in their first year in the process of studying medical and biological physics classes were defined. It is shown that in the test database the number of such tasks averages $8.7 \%$ of the total number of questions on normal human physiology, while in exam booklets it averages $22 \%$. Such data indicate the need for broad involvement of interdisciplinary links in the study of both sciences, which will avoid duplication of educational material in the learning process, opening up prospects for more thorough mastering by students of the program of normal human physiology.
\end{abstract}

Key words: Step-1; interdisciplinary links; medical and biological physics; normal physiology.

Вступ. Якісна медична допомога громадянам є одним із пріоритетів будь-якої розвинутої країни. В умовах реформування охорони здоров'я в Україні найважливішим став процес трансформації медичної освіти, завданням якої є «забезпечення громадян якісною медичною допомогою через високий рівень підготовки медичних фахівців» [6]. Результати дослідження, що містило питання, які стосуються змін у вищій медичній освіті, а саме підсумки опитування соціологічної групи «Рей-

(с) О. З. Іванченко, О. З. Мельнікова, Л. Н. Сергєєва тинг», показали, що «більше 80 \% респондентів підтримують підвищення вимог до вступників на лікарські спеціальності, приблизно стільки ж вважають, що випускний іспит для медиків має бути «дуже складним» (52 \%) і «скоріше складним» (35 \%)» [6].

Вважають, що поліпшенню якості медичної освіти та надання медичної допомоги населенню України сприятиме проведення Єдиного державного кваліфікаційного іспиту (ЄДКІ), який проводить Центр тестування при МО3, що є спеціально 
уповноваженою державною організацією для встановлення відповідності засвоєних здобувачами вищої освіти рівня та обсягу знань, умінь, інших компетентностей вимогам стандартів вищої освіти [3].

Одним із компонентів ЄДКІ є стандартизований іспит «Крок 1», складання якого студентами 3 курсу дозволяє оцінити рівень професійної компетентності із загальнонаукових (фундаментальних) дисциплін. Серед них: біологія, нормальна анатомія, гістологія, нормальна фізіологія, біологічна хімія, патологічна анатомія, патологічна фізіологія, мікробіологія і фармакологія. Роль вивчення фундаментальних дисциплін у вищих медичних закладах має на меті розуміння базових закономірностей розвитку науки, вміння користуватися сучасними знаннями з дисциплін, які допоможуть вирішувати професійні завдання.

На сьогодні критерій складання іспиту «Крок 1» встановлений на рівні 60,5 \% правильних відповідей від загальної кількості питань. «У разі нескладання будь-якого з компонентів кваліфікаційного іспиту здобувач має право повторно скласти іспит не більше одного разу» [3]. Якщо студент не пересклав іспит, то він не допускається до наступної екзаменаційної сесії та відраховується з вищого навчального закладу як такий, що не виконав навчальний план [4].

Підготовка до такого серйозного іспиту потребує від студентів систематичного і якісного навчання. При цьому задачею викладачів є оптимальна, чітка, професійна організація навчального процесу для того, щоб надати необхідні знання, вміння, навички майбутнім лікарям. У першу чергу, це стосується тих кафедр, на яких викладаються дисципліни, що входять до складу іспиту «Крок 1. ЗЛП». Проте ми підтримуємо думку тих авторів, які вважають, що умовою успішного цілісного підходу у викладанні будь-якої дисципліни у вищих медичних навчальних закладах є міждисциплінарна інтеграція [2, 7-9], що вона є «умовою єдності навчання й виховання, засобом комплексного підходу до системи навчання», що «міжнауковий синтез, інтеграція та взаємопроникнення наук набувають масштабного характеру, і міждисциплінарність стає головною особливістю сучасної науки» [1]. У зв’язку з цим ми вважаємо, що кафедри, дисципліни яких безпосередньо не входять до програми ліцензійного іспиту «Крок 1», також повинні ретельно вивчити його питання з метою встановлення і реалізації міждисциплінарних зв’язків. Зокрема, це стосується медичної і біологічної фізики - фундамен- тальної дисципліни першого курсу медичних закладів освіти.

Зіставлення програм дисциплін блоку природничонаукової підготовки лікаря за фахом з програмою з медичної і біологічної фізики показало, що її засвоєння закладає основи подальшого вивчення студентами, насамперед, фізіології людини, а також фармакології і деяких клінічних дисциплін.

Мета статті - проаналізувати зміст тестових питань, які надавалися Центром тестування з дисципліни «Нормальна фізіологія» для підготовки і безпосередньо для складання іспиту «Крок 1». Визначити такі завдання, виконання яких починається студентами 1 курсу на заняттях $з$ медичної і біологічної фізики. Надати необхідні методичні рекомендації для викладачів щодо використання тестів на практичних заняттях з медичної і біологічної фізики у студентів медичного факультету для покращення підготовки до іспиту «Крок 1. ЗЛП».

Теоретична частина. Ми проаналізували буклети для складання іспитів «Крок 1. ЗЛП» (20052017), а також базу тестів для підготовки з дисципліни «Нормальна фізіологія» (2001-2005, 20112014). Всі ці дані надає Центр тестування [5].

Аналіз буклетів проведених іспитів показав, що питання 3 дисципліни «Нормальна фізіологія» складали в середньому 15 \% загальної кількості питань (від 13 до 17 \% у різні роки). Детальне вивчення їх змісту дозволило виявити, що серед них, у середньому, було 3,3 \% таких тестів, які студенти можуть успішно виконати після вивчення дисципліни «Медична і біологічна фізика» (рис. 1).

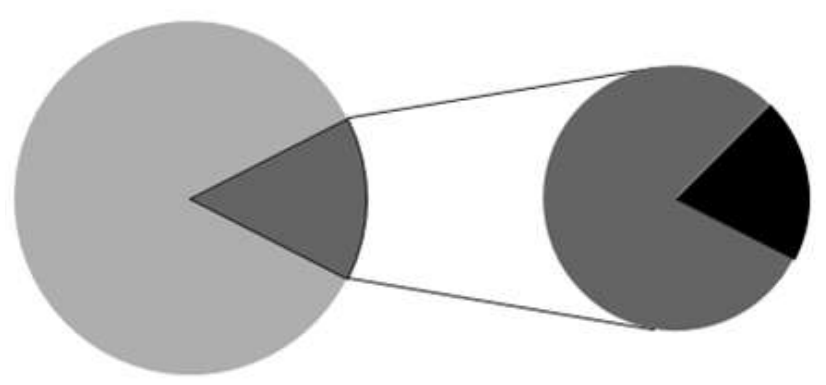

Дисципліни, які входять до складу іспиту «Крок 1. ЗЛП» (окрім нормальної фізіології)

- Нормальна фізіологія

- Медична і біологічна фізика

Рис. 1. Кількість питань (\%) з буклетів іспиту «Крок 1. ЗЛП» за різними дисциплінами загальнонаукової підготовки.

Визначено, що серед питань, які надавалися для підготовки до іспиту з дисципліни «Нормальна фізіологія» (від 205 до 385 питань у різні роки), 
кількість тестів, на які студенти можуть відповісти після вивчення медичної і біологічної фізики, складала в середньому 8,7 \% загальної кількості питань (рис. 2).

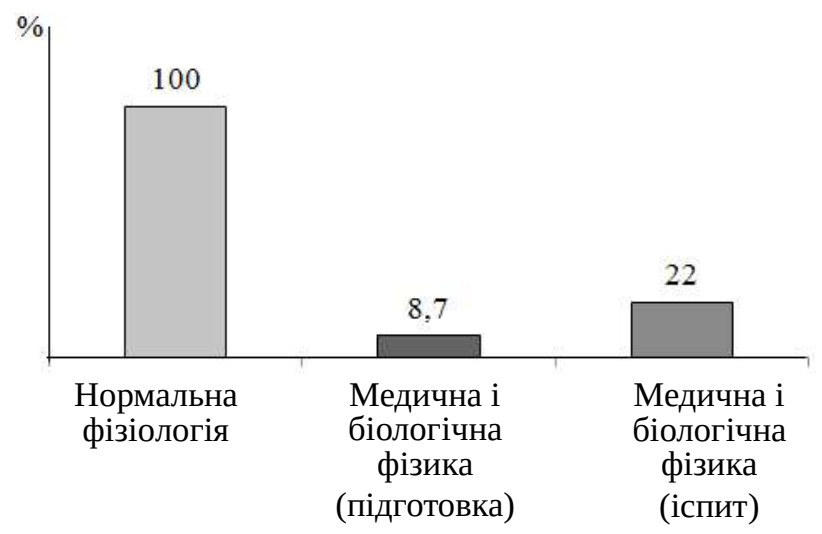

Рис. 2. Кількість питань (\%) з дисципліни «Нормальна фізіологія», які студенти вивчають у курсі «Медична і біологічна фізика», в базі тестів для підготовки та в буклетах проведених іспитів.

Такий результат, а саме те, що в базі тестів для підготовки до іспиту з нормальної фізіології відсоток питань, які вивчаються студентами вже на першому курсі в ході медичної і біологічної фізики, буде невеликим серед загальної кількості питань, є очікуваним. Фізіологія є складною наукою, в якій розглядаються усі процеси життєдіяльності в тілі людини, причому значною мірою на системному і організмовому рівнях, у зв’язку з чим коло питань цієї дисципліни дуже широке. Проте збільшення вказаного відсотка в буклетах для складання іспиту, на наш погляд, потребує особливої уваги до відповідних питань на заняттях з медичної і біологічної фізики.

Тому наступним кроком нашого дослідження було визначення тем курсу «Медична і біологічна фізика», за якими питання представлені в базі тестів для підготовки з дисципліни «Нормальна фізіологія» та в буклетах для проведення іспитів «Крок 1». Результати цього етапу нашого дослідження дозволили виявити теми і провести аналіз відсотків питань із кожної з них, присутніх у базі тестів для підготовки до іспиту і в буклетах для його складання (рис. 3). Загалом такі результати свідчать про необхідність приділити додаткову увагу на заняттях з медичної і біологічної фізики усім представленим темам, i, насамперед, тим, за якими в буклетах велика кількість питань й, особливо, якщо їх відсоток при проведенні іспиту перевищує цей показник в базі тестів для підготовки.
Враховуючи вищевикладені результати дослідження, з метою покращення підготовки студентів для іспиту «Крок 1. ЗЛП», отримані дані враховані при підготовці викладачів до практичних занять за відповідними темами. Розроблено навчальний посібник, в якому надані питання, які в різні роки були включені до бази тестів для підготовки і безпосередньо в буклети для проведення іспиту «Крок 1. ЗЛП». При цьому кожне тестове завдання супроводжується роз'ясненням теоретичних основ. Наприклад, однією з важливіших тем курсу «Медична і біологічна фізика» $є$ тема «Мембранний потенціал спокою. Потенціал дії». На заняттях, згідно з Типовою програмою для спеціальності 222 «Медицина» 3 дисципліни «Медична і біологічна фізика», а також відповідною робочою програмою, розглядаються такі питання, як поняття «мембранний потенціал», знання методів його вимірювання. Студенти повинні розуміти природу мембранного потенціалу, а також знати, як можна розрахувати рівноважний потенціал Нернста, стаціонарний потенціал Гольдмана - Ходжкіна. Серед питань, які вивчаються на занятті «Виникнення і поширення потенціалу дії», обов’язково повинні бути опрацьовані такі поняття: потенціал дії (ПД), його параметри і причини виникнення, іонні механізми різних фаз потенціалу дії. Після вивчення теми студенти мають отримати знання про особливості поширення ПД у збудливих мембранах, знати, від чого залежать швидкість та особливості поширення ПД в аксонах нейронів та інших збудливих мембранах.

Всі зазначені питання висвітлюються студентам на лекції, яка присвячена темі. На практичних заняттях викладачі повинні з' ясувати, наскільки зрозумілим є лекційний матеріал і як студенти опанували відомості за темою самостійно. Для більш ефективного опрацювання матеріалу на практичних заняттях використовуються різноманітні завдання: робота зі схемами, рисунками, вирішення ситуативних і розрахункових задач, тестових питань, навчальні фільми за відповідними темами. До вивчення на практичному занятті обов'язково додаються питання з буклетів іспиту «Крок 1. ЗЛП». Для попередньої підготовки до заняття ми підготували навчальний посібник «Медична фізика i біофізика: збірник завдань для підготовки студентів спеціальності 222 «Медицина» до ліцензійного іспиту Крок 1», в якому наведені питання з відповідної теми взяті зі збірника питань, які пропону- 


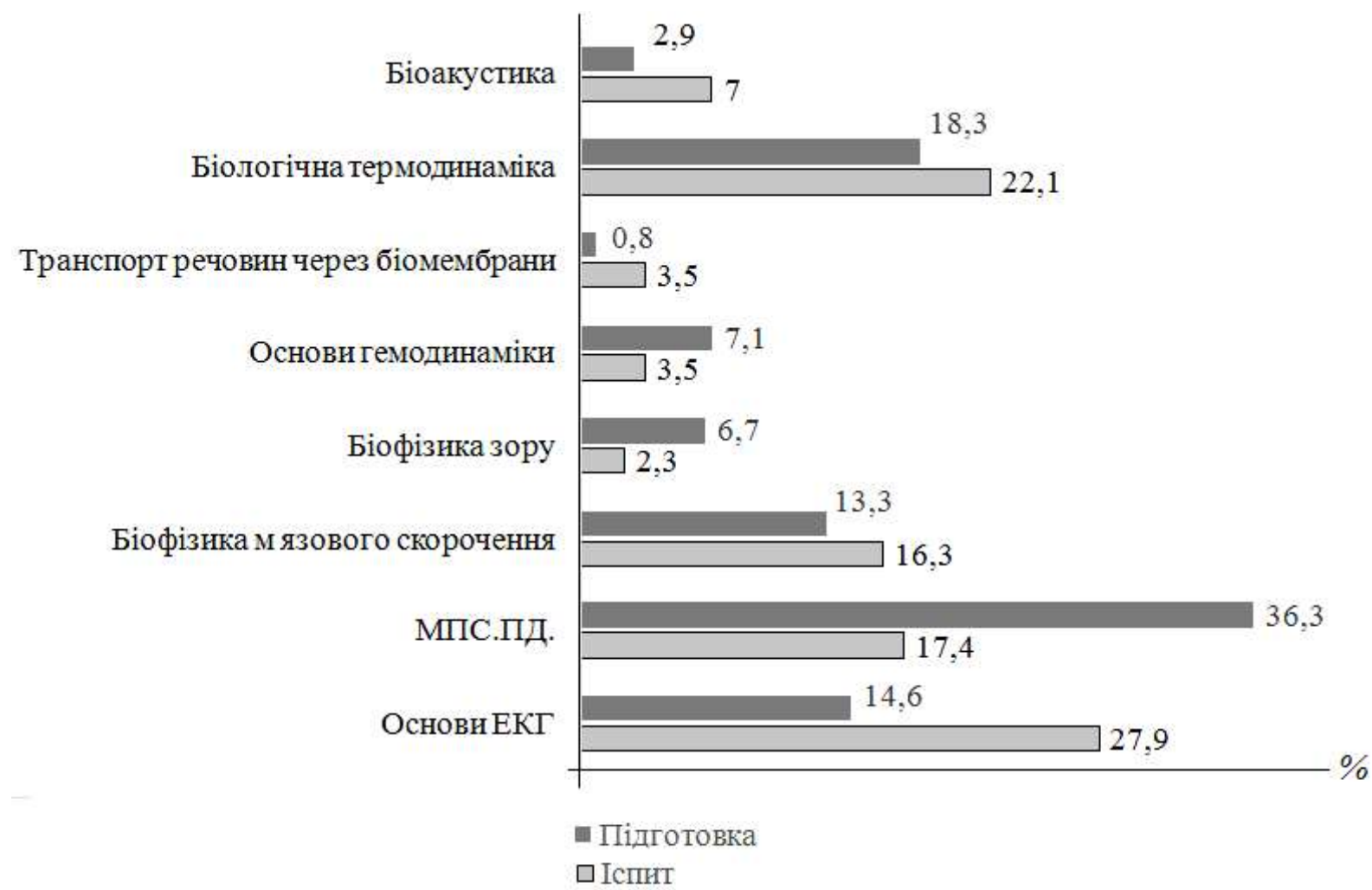

Рис. 3. Питання (\%) за темами курсу «Медична і біологічна фізика», які були надані студентам для підготовки до іспиту «Крок 1» і в буклетах для його проведення.

валися для підготовки до дисципліни «Нормальна фізіологія» в різні роки, а також з буклетів для проведення іспиту «Крок 1. ЗЛП». Потім до кожного питання додається роз'яснення його теоретичних основ для розуміння відповіді на заданий тест. Наприклад, з теми «Мембранний потенціал спокою клітини» одне з питань оформлене так:

«У збудливій клітині повністю заблокували процеси енергоутворення. Внаслідок цього мембранний потенціал спокою:

$A^{*}$. Зникне.

$B$. Незначно зменшиться.

C. Суттєво зменшиться.

D. Незначно збільшиться.

E. Суттєво збільшиться.

Мембранний потенціал спокою створюється внаслідок дифузії іонів калію зсередини клітини назовні. Рушійною силою цієї дифузії є неоднакова концентрація іонів калію всередині клітини і в міжклітинній рідині. Такий розподіл іонів виникає завдяки їх активному транспорту, а саме роботі натрій-калієвого насоса. Активний транспорт потребує витрат енергії АТФ. При блокуванні процесів енергоутворення потенціал спокою зникне».

Одне $з$ питань теми «Виникнення і поширення потенціалу дії по збудливих мембранах» подане в посібнику у вигляді:
«Внаслідок дії електричного струму на збудливу клітину виникла деполяризація ії мембрани. Вхід яких іонів через мембрану до клітини відіграв основну роль у розвитку деполяризації?
$A^{*} . \quad \mathrm{Na}^{+}$.
B. $\mathrm{CO}^{3-}$.
C. $\mathrm{Ca}^{2+}$.
D. $\mathrm{Cl}^{-}$.
E. $K^{+}$.

Деполяризація мембрани виникає в результаті дифузії іонів натрію з оточуючої рідини всередину клітини. Під впливом електричного подразника відбувається зростання проникності мембрани для цих іонів, що зміщує мембранний потенціал у позитивний бік, тобто у бік потенціалу електрохімічної рівноваги іонів натрію».

Аналогічним чином розібрані питання з восьми тем, що представлені на рис. 3. На заняттях інформація подається тільки у вигляді питань (без відповідей). Студенти, прослухавши лекцію, опрацьовують відповідну тему за допомогою рекомендованої літератури, що надається для підготовки до заняття, наприкінці практичного заняття повинні відповісти на питання. Наприклад, після вивчення теми «Реологічні властивості крові. Основи гемодинаміки» студенти повинні знати відповіді на запитання: «В досліді вимірювали лінійну швидкість 
руху крові: вона найменша в капілярах. В чому причина?», «В умовах експерименту у тварини вимірювали залежність артеріального тиску від величини судинного опору. Вкажіть судини, в яких він найбільший», «У людини віком 70 років швидкість розповсюдження пульсової хвилі виявилася значно вищою, ніж у 25-річного. Що є причиною?».

Для більш ретельної підготовки до іспиту «Крок 1» в посібнику також надані за відповідними темами по 50 тестових питань, які розроблені викладачами кафедри. Деякі з них повторюють зміст «крокових» питань, проте сформульовані іншими словами для того, щоб сформувати у студентів вміння мислити і виділяти головну інформацію, а не автоматично запам'ятовувати відповіді з відомих питань бази тестів. Наприклад, питання щодо зубців і комплексів електрокардіограми можуть виглядати дуже коротко, на відміну від тестів бази і буклетів Кроку 1, зміст при цьому зберігається і відповідь правильна зостається тією самою. Наприклад:

Комплекс QRS відображає:

A. Деполяризацію передсердь.

Б. Реполяризацію передсердь.

B*. Деполяризацію шлуночків.

Г. Реполяризацію шлуночків.

Д. Електричну діастолу.

Проте деякі власні питання за темами медичної і біологічної фізики, представленими у Кроці 1, не повторюють за змістом тестів бази і буклетів іспиту. Такі питання є важливими для розуміння процесів життєдіяльності, дозволяють глибше зрозуміти теми і дають змогу студентам бути готовими до тієї частини питань іспиту, яка є варіативною 3 року у рік і не надається студентам для підготовки. Прикладом такого питання за темою «Електрокардіографія» може служити такий тест: «Напрям електричної осі серця до осі першого стандартного відведення ЕКГ склав 130 градусів. Зробіть висновок про ЕКГ:
А. Нормограма.
Б*. Правограма.
В. Лівограма.
Г. Високовольтна.
Д. Високочастотна».

Такі тести в достатній кількості представлені і за іншими темами, оскільки вони сприяють отриманню студентами більш широких і фундаментальних знань. Наприклад, це стосується уявлень про поріг подразнення - вони використовуються в багатьох темах як біофізики, так і фізіології. Тому ці уяв- лення мають бути продемонстровані на багатьох конкретних прикладах, які дадуть змогу студенту зрозуміти, що в будь-яких сенсорних системах, а також у нервовій і м’язовій системах, підвищення порога відчуття або подразнення завжди означає пониження сенсорної або збудливої чутливості. Наприклад, вирішення представленого нижче тесту на занятті з біоакустики виглядає так:

«Збільшення порога чутності звуку будь-якої частоти означає:

А. Збільшення чутливості до нього органа слуху.

Б*. Зменшення чутливості до нього органа слуху.

В. Збільшення області чутності людини.

Г. Зменшення інтенсивності, за якою цей звук чутний.

Д. Цей звук нечутний за будь-якої інтенсивності».

Таким чином, використання різних за змістом тестів для навчання і перевірки в ході контрольних робіт знань студентів за дисципліною дозволить їм більш якісно підготуватися до складання ліцензійного іспиту «Крок 1», сприяючи більш широкому і ретельному розгляду фізичних і фізико-хімічних основ процесів життєдіяльності в тілі людини.

Ми вважаємо, що систематичний підхід до підтримання вертикальної міждисциплінарної інтеграції сприятиме формуванню у студентів цілісного «сприйняття фундаментальних закономірностей розвитку науки» [2], а також здійсненню основних принципів навчання у вищому навчальному закладі, а саме отриманню міцних знань, усвідомленню значущості та вмінню використовувати їх на практиці [8]. На сьогодні ми спостерігаємо значне підвищення мотивації до вивчення медичної і біологічної фізики як основи для наступного оволодіння інтегрованими з нею дисциплінами, якими є нормальна і патологічна фізіологія, фармакологія та деякі інші, що, у свою чергу, сприятиме створенню міцної і якісної бази для вивчення всіх фундаментальних і клінічних дисциплін, які необхідно опанувати майбутнім фахівцям у період їх навчання в медичному університеті. Нам здається безумовно важливою і правильною думка авторів [2, 7-9] про те, що застосування міждисциплінарних технологій підготовки лікаря дозволить підняти його на якісно новий рівень клінічного мислення, здатного комплексно вирішувати завдання медичної практики на основі широкого інтегрування знань із різноманітних дисциплін.

Висновки та перспективи подальших досліджень. Потреба виявлення, опрацювання, використання в навчальному процесі міждисциплінарних 
зв'язків $є$ необхідною складовою підготовки майбутніх фахівців. При вивченні медичної і біологічної фізики та нормальної фізіології встановлення й застосування міждисциплінарної інтеграції сприяє ретельному засвоєнню обох дисциплін, дозволяє уникати дублювання навчального матеріалу в процесі навчання, а також є необхідною складовою для успішного складання ліцензійного іспиту «Крок 1».

Аналіз питань ліцензійного іспиту «Крок 1» виявив ті з них, які студенти починають опрацьовувати вже на 1 курсі протягом вивчення медичної і біологічної фізики, яка має найбільш виражені інтеграційні зв'язки з нормальною фізіологією, а також з іншими дисциплінами природничо-наукової підготовки.

Удосконалення використання міждисциплінарних зв'язків при викладанні медичної і біологічної фізики є необхідним для формування у студентів системного, усвідомленого погляду на фундаментальні науки і реалізується шляхом створення необ-

\section{Список літератури}

1. Іленко Н. М. Міждисциплінарні зв’язки як фактор вдосконалення вивчення предмету терапевтична стоматологія при підготовці майбутнього лікаря / Н. М. Іленко, О. Н. Бойченко // Вісник проблем біології і медицини. 2018. - Вип. 4, T. 2 (147). - С. 223-225. DOI: https://doi. org/10.29254/2077-4214-2018-4-2-147-223-225.

2. Карпець М. В. Міждисциплінарна інтеграція - основа професійної спрямованості навчання / М. В. Карпець // Світ медицини та біології. - 2016. - № 4 (58). C. $144-147$.

3. Постанова Кабінету Міністрів України від 28.03.2018 р. № 334. - Режим доступу : https://zakon. rada.gov.ua/laws/show/334-2018-п.

4. Про вищу освіту : Закон України від 01.07.2014 р. № 1556-VII [Електронний ресурс]. - Режим доступу : http://zakon2.rada.gov.ua/laws/show/1556-18.

\section{References}

1. Ilenko, N.M., Boichenko, O.N. (2018). Mizhdystsyplinarni zviazky yak faktor vdoskonalennia vyvchennia predmetu terapevtychna stomatolohiia pry pidhotovtsi maibutnoho likaria [Interdisciplinary relationships as a factor of improving the study of therapeutic dentistry in preparing the future doctor]. Visnyk problem biolohii i medytsyny Bulletin of Problems of Biology and Medicine, 4, 2 (147), 223-225. DOI: https://doi.org/10.29254/2077-4214-20184-2-147-223-225.

2. Karpets, M.V. (2016). Mizhdystsyplinarna intehratsiia osnova profesiinoi spriamovanosti navchannia [Interdisci- хідної навчальної літератури, в якій використовуються найсучасніші уявлення, відомості і методи дисциплін, які інтегруються в природничо-науковому блоці.

У подальшому для успішного застосування міждисциплінарної інтеграції в процесі навчання ми вважаємо доцільним у навчально-методичній роботі кафедр активізувати підготовку і складання різноманітних тестів, ситуаційних та розрахункових задач, які розвивають мислення студентів і забезпечують найкращу підготовку до ліцензійного іспиту, включаючи його варіативну частину. Крім того, потрібно проаналізувати зміст його питань щодо міждисциплінарних зв’язків медичної і біологічної фізики з клінічними дисциплінами з метою більш глибокого розуміння майбутніми лікарями фізичних основ діагностичних і терапевтичних методів, які використовує сучасна медицина, а також ролі фізичних факторів навколишнього середовища в життєдіяльності людини в нормі і патології.

5. Сайт центру тестування. - URL : https://www. testcentr.org.ua/uk/.

6. Стратегія розвитку медичної освіти в Україні. Режим доступу : https://moz.gov.ua/ strategija-rozvitkumedichnoi-osviti.

7. Atwa H. S. Curriculum integration in medical education: A theoretical review / H. S. Atwa, E. M. Gouda // Intel. Prop. Rights. - 2014. - 2. - P. 113. DOI: https://doi.org/10.4172/ 2375-4516.1000113.

8. Integrated medical curriculum: advantages and disadvantages / G. A. Quintero, J. Vergel, M. Arredondo [et al.] // J. Med. Educ Curric. - 2016. - Vol. 3. - P. 133-137. DOI: https://doi.org/10.4137/JMECD.S18920.

9. Loftus $S$. Understanding integration in medical education / S. Loftus // Med. Sci. Educ. - 2015. - 25. - P. 357-60. DOI: https://doi.org/10.1007/s40670-015-0152-4.

plinary integration - the basis of professional orientation training]. Svit medytsyny ta biolohii - World of Medicine and Biology, 4 (58), 144-147 [in Ukrainian].

3. Postanova KMU vid 23.11.2011 r. No 1341 [Resolution of Cabinet of Ministers of Ukraine No. 334 of March, 03 2018.] Retrieved from: https://zakon.rada.gov.ua/laws/ show/334- 2018-п [in Ukrainian].

4. Zakon Ukrainy "Pro vyshchu osvitu” vid 01.07.2014 r. No 1556-VII [On higher education: Law of Ukraine of 01.07.2014 No. 1556-VII]. Retrieved from: http: // zakon2. rada.gov.ua/laws/show/1556-18 [in Ukrainian]. 
5. Sait tsentra testuvannia [Test center site]. Retrieved from: https://www.testcentr.org.ua/uk/ [in Ukrainian].

6. Stratehiia rozvytku medychnoi osvity v Ukraini [Strategy for the development of medical education in Ukraine]. Retrieved from: https://moz.gov.ua/ strategija-rozvitkumedichnoi-osviti [in Ukrainian].

7. Atwa, H.S., Gouda, E.M. (2014). Curriculum integration in medical education: A theoretical review. Intel. Prop. Rights, 2, 113. DOI: https://doi.org/10.4172/ 23754516.1000113.
8. Quintero, G.A., Vergel, J., Arredondo, M., Ariza, M-C., Gómez, P., Pinzon-Barrios, A-M. (2016). Integrated medical curriculum: advantages and disadvantages. J. Med. Educ. Curric. 3. 133-137. DOI: https://doi.org/10.4137/JMECD. S18920.

9. Loftus, S. (2015). Understanding integration in medical education. Med. Sci. Educ., 25, 357-360. DOI: https:// doi.org/10.1007/s40670-015-0152-4.

Отримано 16.11.20

Рекомендовано 18.11.20

Електронна адреса для листування: elenazenonovna71@gmail.com 